\title{
THE GREATEST REQUIREMENT OF SENSE OF MODERN EDUCATION: INDIVIDUAL ATTENTION AND TEACHING-FAMILY MODEL $^{1}$
}

\author{
MODERN EĞİTIMM ANLAYIŞININ EN BÜYÜK GEREKSINIIMİ: BİREYSEL İLGİ VE \\ AİLE ÖĞRETMENLİĞİ MODELİ
}

DOI:10.17755/esosder.25569

\begin{abstract}
Abdullah ADIGÜZEL ${ }^{2}$
Abstract

The objective of this research is to determine the opinions of students related to "Teaching-Family Model" proposed with the purpose of supporting their school learning and allowing them to prepare for central examinations. The research was conducted with the participation of students in $10^{\text {th }}$ and $11^{\text {th }}$ grades of high schools and in $6^{\text {th }}$ and $7^{\text {th }}$ grades of secondary schools in the central district of Şanliurfa in the spring semester of the 2014-2015 academic year. Total 120 students -60 of which are in $6^{\text {th }}$ and $7^{\text {th }}$ grades from 3 secondary schools and 60 of which are in $10^{\text {th }}$ and $11^{\text {th }}$ grades from high schools- specified in the centre of Şanliurfa were selected. In the research made according to the qualitative research technique, data were collected by semistructured interview form. The students who participated in the research stated that the model was apprehensible and applicable. The opinions of students requesting a Teaching-Family centre having teachers in all branches to give individual attention to the students were grouped into three sub-themes. As related to the first sub-theme, the students expressed their complaints about too crowded classes in the school. The second sub-theme including the opinions of students is the matter that the teachers do not give individual attention to the students and the lessons are taught without considering the individual characteristics of the students so they fail to understand the lessons. And the third sub-theme including the opinions of students is the fact that the family structure and houses of the students are not suitable for studying.
\end{abstract}

Keywords: Individual attention, teaching family, individual differences, school, student, central examination

\section{$\ddot{\mathbf{O z}}$}

$\mathrm{Bu}$ araştırmada amaç, “Aile Öğretmenliği Modeline” ilişkin öğrencilerin görüşlerini belirlemektir. Araştırma, 2014-2015 eğitim-öğretim y1lı güz döneminde Şanlıurfa merkez ilçede bulunana ortaokullarda okuyan 6 . ve 7 . Sınıf öğrencileri ile liselerde okuyan 10. ve 11. Sınıf öğrencilerinin katılımıyla gerçekleştirilmiştir. Şanlıurfa merkezde belirlenen 3 ortaokuldan 6 . ve 7 . sinıflardan 60 ve liselerden 10 . ve 11 sinıflardan 60 öğrenci seçilmiştir. Araştırmaya toplam 120 öğrenci katılmıştır. Öğrencilerle bireysel olarak ilgilenecek her branşta öğretmenin bulunduğu bir Aile Öğretmenliği merkezlerinin olmasını isteyen öğrencilerin görüşleri üç alt temada gruplandırılmıştır. Birinci alt temaya ilişkin olarak öğrenciler okullardaki sınıfların çok kalabalık olduğuna ilişkin şikâyetlerini dile getirmişlerdir. Öğrenci görüşlerinin yer aldığı İkinci alt tema ise okullarda öğretmenlerin öğrencilerle bireysel olarak ilgilenmediği ve öğrencilerin bireysel özellikleri dikkate alınmadan derslerin işlendiği bu yüzden derslerin yeterince anlaşılmadığı konusudur. Öğrenci görüşlerinin yer aldığı üçüncü alt tema ise öğrencilerin aile yapılarının ve evlerinin ders çalışmaya uygun olmamasıdır.

Anahtar Kelimeler: Bireysel ilgi, aile öğretmenliği, bireysel farklılıklar, okul, öğrenci, merkezi sınav

\footnotetext{
${ }^{1}$ This study, Presented Orally in Congress, "International Congress on Education for the Future: Issues and Challenges"

${ }^{2}$ Doç.Dr.,Eğitim Bilimleri Bölümü, aadgzel@gmail.com
} 


\section{INTRODUCTION}

It is known that people have various abilities at different levels. Therefore, before determining what and how individual can learn, individual characteristics caused by his/her nature should be determined (Kuzgun \&Deryakulu, 2004). Individual teaching is the development of each individual in line with his/her own personality structure, interest, abilities and requirements and so his/her participation to society as a constructive member (Özgüven, 2005). Even though students in the classes are of the same age, there are individual differences among them. This means that all of the students cannot learn the same subject at the same level at the same time. Thus, different learning environments and teaching methods should be used in education, because different learning environments offer students with individualized learning opportunities such as different learning approaches, learning sources and materials according to their individual characteristics (Brown, 2007; Brusilovsky \& Peylo, 2003). When considering the time allocated by teachers for each student so as to give individual attention to students, it is known that some of the students in the class learn quickly, some of them learn slowly and some of them learn too late. This leads to various problems in the course of teaching-learning in the class. It is possible to overcome these problems only by individualizing the education and through special attention (Doğanay, 2007). This reveals different learning ways and environments accepted as the way preferred for obtaining, using and saving the information (Brown, 2007; Brown at al., 2007; Latham at al., 2010; Wolf, 2003).

Although different learning approaches of students are the sole factor for learning at different levels, they are accepted as one of the most important components of learningteaching period (Ekici, 2003). The success can be defined as a measure or an indication to what extent the individual makes use of a specific discipline or academic program in the school environment (Özgüven, 2005). Creating learning environments suitable for the characteristics and learning approaches of students facilitates learning (Özyurt at al., 2014). Individual teaching support should be provided when students should be supported for their learning or in case of difficulty in learning in the teaching-learning period (Reece, 1997). There various teaching practices considering the individual characteristics of students. For instance, tutorials correct instantly the mistakes of students by giving individual attention to them and also correct their deficiencies (Tan, 2006). On the other hand, web based teaching environments are frequently used with the purpose of conducting individual teaching (Brown, 2007). However, these systems are widely criticized in that they provide the same content for student having different learning goals and ways, because there are significant deficiencies in considering individual learning and differences in these alternatives (Brown at al.., 2009; Cabada at al., 2011). Individual differences among students are one of the most important factors for creating and popularizing new learning environments. Thus, individualized learning opportunities such as different learning strategies, sources, environments and solution supports should be provided for students by considering their individual differences (Brown, 2007; Mustafa \&Sharif, 2011).

Families who can have their children take private lesson know that special attention increases the success of child, because a teacher can only give individual attention to certain students and can also see and correct instantly their mistakes. However, as every student doesn't have the opportunity to receive private lesson, it is difficult to find a teacher who can tutor for every student. Regulations to correct the deficiencies out of the school are required for determining and overcoming wrong and inadequate learning of students and facilitating learning of students (Tan, 2006). It is a known fact that the education system in Turkey has examination based structure and students at almost all education levels prepare for central examinations (Bilge at al., 2014).In this regard, students endeavour to show better 
performance than their classmates by focusing on proving themselves in these examinations (Ames, 1992). In order to provide equality of opportunity for students having different learning opportunities and offer them with better preparation opportunity for central examinations and allow them to improve themselves, applications such as "Teaching-Family Model" are required.

\section{Teaching-Family Model}

In Turkey as such in many countries in the world, transition from secondary schools to high schools and from high schools to universities is conducted with central examinations. For this purpose, it is known that students receive educational support which is preparatory for examinations in various private educational institutions in addition to education services provided for them by the State. It is known that individual schooling operations under the name of training centre, advice centres, student coaching, studying centres etc. become popular. However, the policies and decisions of the State relating to these centres and activities are continuously changing. All of these shows that students who cannot prepare for examinations in an adequate level with the education opportunities offered in schools by the State seek for alternative ways. Therefore, new additional regulations to support current school system are required so that the education system can become adequate for itself. This system should be based on a guidance approach providing student follow-up both in family and school, following the student individually, seeing and correcting mistakes and deficiencies in his school learning, leading and recording, being in cooperation with family, keeping in touch with student. When considering such system as a model, it is possible to define it as "Teaching-Family Model". In Teaching-Family Centres, there will be various teachers in all branches included in central examinations such as the Transition from Primary to Secondary Education Exam (TEOG), the Transition to Higher Education Exam (YGS) and Undergraduate Placement Exam (LYS). Thus, students who take lessons regularly in schools will be followed and supported by teachers in these centres.

\section{Basic Principles of Teaching-Family Model}

Teaching-Family Model should be conducted depending upon the following principles in order to continue properly for the purpose of foundation and contribute to the school success of students.

1. Teaching-Family Centres will be founded in almost every district or neighbourhood and provide service for all families having school-age children.

2. Teaching-Family Centres will have the information of all secondary school-aged and high school-aged students in their region.

3. Teaching-Family Centres will be public enterprises and those who work in there and teachers will be public personnel.

4. As in all public enterprises, these centres have also a management, operation and budget.

5. The number of teachers employed according to their branch and education levels will be determined according to the secondary school-aged and high school-aged children population in that district or neighbourhood. As there is no central examination in transition from primary to secondary school and one teacher gives attention to students for all lessons during 4 years in the primary school, there is no need for form teachers in these centres.

6. Each teacher will be responsible for maximum 12 students in his/her branch and the teacher will only give attention to the students in his/her branch. 
7. Teachers will keep development reports relating to the students for whom they are responsible and will also follow the changes.

8. Teachers will continuously keep in touch with the family and school of student for getting information about the student for whom they are responsible.

9. Teachers in Teaching-Family centres will not have authority in respect of pass-fail grading of student, changing their schools and the placement in a school.

10. There will be one-to-one study rooms, study halls and multiple learning environments in these centres.

\section{Application Examples in the World}

It is known that the applications similar to "Teaching-Family Model" considered to meet a significant requirement and to fill a significant gap in primary and secondary schools are made in world's various countries. Additionally, this model can be considered as professionalizing the uncontrolled studies centres in an ordered and organized manner by regulating them. In his study, Şimşek (2010) stated that the studies centres emerged in Selanik in 20th century and became popular and came until today due to the need of children for educational support out of the school. On the other hand, even if its application way and purpose differ slightly, it is known that there are family based educational applications. We can summarize some of these applications as follows:

“Achievement place: The teaching-family model" proposed by Wold, Philips, Fixsen and Braukman in 1976 offers protection and treatment-purpose family based solutions due to increased stimuli prompting teenagers to undesired forms of behaviour. According to the model, the most effective way of protecting teenagers against stimuli affecting them adversely and educating them successfully is to organize family based education and treatment activities and popularize this model as a community based movement (Wolf at al., 1976). Another study especially emphasizing the importance of family in the baseline level of educational treatment applications is a model named "Teaching family at the introductory level: conceptual model emphasizing pattern which connects training and therapy" proposed by Liddle \& Saba in 1982. The model defines family based education with a metaphor which associates parallelism between teaching and treatment. The model explains that the family based education can be conducted in three stages such as combination, restructuring and consolidation and these stages have different goals and methods (Liddle \& Saba, 1982).

In the study named "Towards a unified perspective on human service delivery systems: Application of the Teaching-Family Model" proposed by Bernfeld, Blase and Fixsen in 1990, they examine points of views relating to giving educational support for people through teaching-family. Abstract fields of behavioural sciences got to be locked with the effect of technology emerging for wide range of problems solving and treatment for people. Thus, the model argues that the family based educational activities should be provided for people (Bernfeld, at al, 1990). As for Kirigin, Braukmann and Atwater (1982), in their model named "An evaluation of teaching-family group homes for juvenile offenders", they offer group homes with the purpose of not pushing children into crime and educating juvenile offenders. In an education program to be prepared for this purpose, it is emphasized that home programs should be arranged and the frequency of education activities in proper places should be increased (Kirigin at al., 1982).

Wrestling (1995) explains the need of developing and refining family based program with a case study in this study named "The Teaching Family Model A Case Study in DataBased Program Development and Refinement". The model emphasizes that a family based education program will be more humane and community-based. It is thought that family 
based education programs will increase the quality of life of people, decrease the risks, avoid lack of planning and initiate the technological development (Wrestling, 1995). Hund (2013) states that creating and conducting the group learning approaches by associating with the family environment will increase the learning performance of student in his model named as "The Social Family Model of Teaching" loaded to Prezi educational web site. In this model, basic characteristics providing efficiency in learning such as students' learning from each other, cognitively and socially high motivation and performance, individual and team work, feedback and revisions are taken as basis (Hund, 2013). Dean et al. developed their model named as "In Search of Program Implementation: 792 Replications of The Teaching Family Model" in 1999, published it as book in 2001 and then made criticism on it in the magazine named "The Behaviour Analyst Today" in 2007. The model developed as solution oriented adopts a gradual approach in solving the significant social problems such as child abuse, offense and ignorance. Authors insisting on educational proposals and approached within the scope of "family model" in solving all social problems tried to provide the model application by taking 792 steps during their 15-year experiences and stated that it had been applied in North America over about 30 years (Dean at al., 2001; Dean at al., 2007). The observations of educators indicate the students' need for educational support out of the school and the importance of the effect of family on child (Şimşek \& Şimşek, 2014). For this reason, children and teenagers should receive support from psychologists, teachers, parents and other professionals in order to increase their school success (Moolla \& Lazarrus, 2014; Jimerson at al., 2007).

It is seen that these family based application models focus on five basic objectives. These are: increasing the school success of students, preparing the students for central examinations, avoiding and protecting students from acquiring undesired bad habits, treating the students who acquire undesired bad habits and providing all with the education opportunity. In this regard, individuals different from each other in various aspects prefer different learning ways and different learning environments during learning period. Instead of trying to make them similar by addressing all of individuals having different characteristics through the same environment and the same learning way, this study was designed in line with the thought that determining the learning approaches required to be considered as a wealth during the application process and arranging new education environments will increase the success of students in central examinations.

\section{Research Objectives}

The objective of this research is to determine the opinions of students relating to "Teaching-Family Model". The following questions were tried to be answered in the research.

1. What are the opinions of students related to the existence of a centre in which there are teachers in all branches that they can go after the school and give individual attention to them?

2. What are the opinions of students related to the centre either of private sector (paid) or state (free)?

3. What are the opinions of students related to whether a system to guide and repeat individually a lesson hard to learn after the school will increase their school success?

4. What are the opinions of students related to whether they are bothered by teachers constantly giving attention to them, correcting their deficiencies after the school, following them in the school and informing their family or school about them? 


\section{METHOD}

This research was conducted by using the case study technique of qualitative research methods. The research focuses on the questions "why?" and "how?" as it is about a new model proposal to be established in order to support the school learning of students. With these questions it is aimed to examine the model proposed deeply and in more detail. Yin (2003) proposes that the case study technique should be used when the case aimed is required to be examined deeply and in detail. Moreover, the embedded single case design of study case technique is used for detailing the proposed model and revealing the details. With this design, it was aimed to reveal detail opinion about "Teaching-Family Model". When multiple subsets or units are required to be created for a case or question, this design can be preferred (Yildırım \& Şimşek, 2008). The case which is handled in the research is the opinions of students about "Teaching-Family Model" proposed for supporting the school studies of students and increasing their success. Sub dimensions and details emerging a result of opinions will be examined with the embedded structure of sub analysis units included in the case and the research case will be explained in detail.

\section{Study Group}

The research was conducted with the participation of students in $10^{\text {th }}$ and $11^{\text {th }}$ grades of high schools and in $6^{\text {th }}$ and $7^{\text {th }}$ grades of secondary schools in Şanliurfa in the spring semester of the 2014-2015 academic year. Total 60 students -30 of which are from $6^{\text {th }}$ grades, 30 of which are from $7^{\text {th }}$ grades of 3 secondary schools- were selected. Thus, total 120 students participated in the research. The information on the objective, subject and interview technique of research was given by interviewing with the students participating the research and the management of schools chosen. In the research, "Teaching-Family Model" was introduced in detail to the students. As the research was conducted with the students at two education step levels, symbols from (A) 1 to 60 for secondary schools and symbols from (B) 61-120 for high schools were used and numbered. A1, A2 and A3 for secondary school and B1, B2 and B3 for high school were used, as there were several school numbers at every education step. Additionally, symbols such as S6 for $6^{\text {th }}$ grade, S7 for $7^{\text {th }}$ grade of secondary school and S10 for $10^{\text {th }}$ grade, S11 for $11^{\text {th }}$ grade of high schools were created. All participants were volunteers and 54 of which consisted of girls and 66 of which consisted of boys. The distribution of the study group and participants of research according to gender is given in Table 1.

Table 1. Distribution of Research Study Group and Participants According to Gender

\begin{tabular}{|c|c|c|c|c|c|c|c|c|c|}
\hline \multirow[t]{3}{*}{ Schools } & $\begin{array}{c}\text { Participant } \\
\text { Code }\end{array}$ & \multirow{2}{*}{$\begin{array}{l}\text { Participant } \\
\text { Number }\end{array}$} & \multicolumn{2}{|c|}{ Participant Code } & \multirow{3}{*}{$\begin{array}{c}\text { Participant Number and } \\
\text { Intervals } \\
\end{array}$} & \multicolumn{4}{|c|}{ Gender } \\
\hline & \multirow{6}{*}{\multicolumn{2}{|c|}{ Secondary School }} & \multirow[t]{2}{*}{ A1 } & \multirow{2}{*}{$\begin{array}{l}\text { S6 } \\
\text { S7 }\end{array}$} & & \multicolumn{2}{|c|}{ Girl } & \multicolumn{2}{|c|}{ Boy } \\
\hline & & & & & & $\mathrm{f}$ & $\%$ & $\mathrm{f}$ & $\%$ \\
\hline & & & A2 & S6 & $60(1-60)$ & & & & \\
\hline & & & & S7 & & & & & \\
\hline & & & A3 & S6 & & 54 & 45.00 & 66 & 55.00 \\
\hline & & & & S7 & & & & & \\
\hline & High Scho & & B1 & S10 & & & & & \\
\hline & & & & S11 & & & & & \\
\hline & & & B2 & S10 & $60(61-120)$ & & & & \\
\hline & & & & S11 & & & & & \\
\hline & & & B3 & S10 & & & & & \\
\hline & & & & S11 & & & & & \\
\hline
\end{tabular}




\section{Data Collection Tool}

In the research, data were collected through semi-structured interview form consisting of six open-ended questions and prepared as related to the "Teaching-Family Model". The open-ended questions were used for determining the opinions of student about "Teaching-Family Model' and collecting data about the applicability of model. In the research, the students were asked to express their opinions in written and for this reason the opportunities were provided for them. This way was followed with reference to the fact that students could explain their opinions which they were shy of more easily in written. Different classifications related to the interview technique were made in literature. Fielding (1966) grouped the interviews as; "standardized", 'semi-standardized" and 'non-standardized'. Minichiello (1990) also grouped the interview technique as; 'structured", 'semi-structured"' and "unstructured". In this research, data were collected by receiving students opinions with a semi-structured form in which there were questions related to "Teaching-Family Model" and the literature regarding the subject was scanned. In consideration of data obtained, the interview form was prepared and it was reviewed by five assistant professors in the field of educational sciences, then the form was put into its final form in accordance with their opinions and suggestions. It took between 10-15 minutes for the students to answer the six open-ended questions included in the interview form.

The open-ended questions in the semi-structured interview form prepared for receiving students opinions about the model

1. Do you think that you can clearly understand the "' Teaching-Family Model"? Explain.

2. Do you think that can 'Teaching-Family Model' can be applied? Explain.

3. In the district where you live in do you want a centre where you can go after the school and in which there is a teacher in all branches giving individual attention to you? Explain with reasons.

4. How do you want that this centre gives you educational support by state (free) or private sector (paid)? Explain with reasons.

5. If there would be a system which helps and guides you about your lesson face to face and repeat it to you after school in which you have difficulty in learning it. Would it help you raise your success at school and central examinations? Explain with reasons.

6. Will you be bothered with the presence of the teachers constantly giving attention to you, correcting your deficiencies after the school, following you in the school and informing your family or school about you? Explain with reasons.

\section{Validity and Reliability}

In the validity and reliability study of this research which was done for applicability of the model, the following processes were conducted.

When preparing the interview form, for increasing the cogency of the research in other words providing the internal validity, as a result of searching the related literature and the opinions of instructors, a conceptual framework relating to the "Teaching-Family Model" was formed. Within this framework, the written opinions of the students which were collected were subjected to the content analysis technique and the opinions of students were classified considering the main themes and sub-themes formed related to the model. For data collection process, permission was obtained from all managements of the schools and the model was 
only presented only for volunteer students and the forms consisting of questions were given. For ensuring the consistency and increasing the internal reliability in the research, no comment was made about the findings. They were only classified considering the main themes and sub-themes. But the misspellings and incoherencies of the students were tried to be corrected without touching the meaning of the phrase. For ensuring the external reliability of the research in the process of conducting the research, the processes made especially in the method section were tried to be explained individually and in a detailed way. Accordingly, as seen above; the model of the research, study group, data collection tool, data collection process, the process of analysing and interpretation of data were described directly and clearly.

\section{Analysis and Interpretation of Data}

In this research conducted for the applicability of the model, the content analysis technique suggested by Şimşek (2008) was used for the analysis of data collected depending upon the opinions of students. Thus, the collected data were identified and the facts and details maybe hidden in data were revealed. The descriptive analysis of data collected for the applicability of the model was made through the following processes.

1. All the opinions collected were arranged without making lexical correction on them and printed in accordance with the main theme and sub-themes according to the order in the form.

2. A thematic framework was formed depending upon the collected data and the codes were given to the determined themes.

3. In the direction of thematic framework, data were read and the frequency values of the themes were revealed. These themes were grouped under the main topics. The subthemes were formed under the determined main themes and the frequency values for every main theme and sub-themes were revealed.

4. The data collection forms were divided into two groups; A (1-60) for secondary schools, B for (61-120) high schools and arranged in order. Each article in the forms was read one by one and common ideas were coded under an answer.

\section{FINDINGS AND COMMENTS}

In the research, the frequency distributions were made according to the answers of the students regarding the model and were tabulated. The tables were interpreted and examples were given from the opinions that the students expressed. The opinions of students regarding their understanding about the model are given in Table 2.

Table 2. Opinions of Students Related to Their Understanding of the "'Teaching-Family Model",

\begin{tabular}{|c|c|c|c|}
\hline Main Theme & Education level & Sub-Themes & f \\
\hline & & Yes & 48 \\
\hline Understanding of students on the "Teaching-Family & Secondary School & Partially & 8 \\
\hline \multirow[t]{4}{*}{ Model"' } & & No & 6 \\
\hline & & Yes & 56 \\
\hline & High School & Partially & 4 \\
\hline & & No & -- \\
\hline
\end{tabular}

As seen in Table 2, while 48 of secondary school students answered "yes" to the question of "did you understand the "Teaching-Family Model"?", 8 of which answered "partially" and 6 of which said that they didn't understand it. A secondary school student who claimed that he/she understood the model stated, "So everybody would have a school 
and tutors? (A3S6-47)', Another student said, 'Will the state open the studies centres? (A1S6-7)'. While 56 of the 60 high-school students participating into the research indicated that they rightly understood the model, 4 of which said that they understood it partially. In this regard, it can be said that high-school students have a better understanding about the model than secondary school students. This can arise from the fact that high-school students are older than the secondary school students and they are at the next education level. One of the high-school students who said that he understood the model tried to satisfy his/her curiosity about the applicability of the model with a question as "Will these centres be opened in the evenings and at the weekends or will they be opened only in the day time on weekdays like schools? (B2S11-89)', The opinions of students related to the applicability of the model are given in table 3.

Table 3: Opinions of Students related to the Applicability of "Teaching-Family Model"

\begin{tabular}{llll}
\hline Main Theme & Education Level & Sub-Themes & f \\
\hline \multirow{3}{*}{ Applicability of "Teaching-Family Model" } & & Yes & 44 \\
& Secondary school & Partially & 8 \\
& & No & 8 \\
& & Yes & 6 \\
& High school & Partially & 8 \\
\hline
\end{tabular}

44 of secondary school students and 46 of high school students stated that the model was applicable. While 8 of secondary school students stated that the model was partially applicable, 8 of which stated that it was non-applicable. While 6 of high school students stated that the model was partially applicable, 8 of which stated that it was non-applicable. When considering the point of view of all students participating in the research, it is seen that more than three fourths of students stated that the model was applicable. It can be said that the reason why high school students pay more attention to the model is the fact that they want to enter a university and have a profession.

A high school student stating that the model is applicable has made an explanation as follows by giving example of the application of "Family Practice" in community health centres: There is a community health centre in our neighbourhood, each of the doctors in these centres takes care of certain families. We have also a family doctor. We always go to this doctor (B2S11-101). Another high school student explains the applicability of model with an alternative approach: If the State cannot construct a new building for "Teaching-Family Model", separate rooms can be reserved for branch teachers giving individual attention to students within the school (B3S10-87). A secondary school student stating the nonapplicability of model expressed his/her opinion by saying "How they will find teachers to give individual attention to such a great number of students (A1S7-12)". The opinions of students related to the demand of existence of a centre where there are teachers in all branches are stated in Table 4.

Table 4. Opinions of Students Related to the Demand of "Teaching-Family Model"

\begin{tabular}{|c|c|c|c|c|c|}
\hline Main Theme & $\begin{array}{l}\text { Education } \\
\text { Level }\end{array}$ & Answers & f & Sub-Themes & f \\
\hline \multirow{7}{*}{$\begin{array}{l}\text { Demand of students for the } \\
\text { existence of centre where } \\
\text { they can go after school and } \\
\text { there are teachers in all } \\
\text { braches who will give } \\
\text { individual attention to them }\end{array}$} & \multirow{3}{*}{$\begin{array}{l}\text { Secondary } \\
\text { school }\end{array}$} & Yes & 41 & Too crowded classes & 32 \\
\hline & & Partially & 7 & \multirow{3}{*}{$\begin{array}{l}\text { Not giving individual attention to the } \\
\text { students in schools }\end{array}$} & \multirow{3}{*}{26} \\
\hline & & No & 12 & & \\
\hline & \multirow[t]{3}{*}{ High school } & Yes & 48 & & \\
\hline & & Partially & 8 & \multirow{2}{*}{$\begin{array}{l}\text { Not suitable family environments for } \\
\text { students' studying }\end{array}$} & \\
\hline & & No & 4 & & 13 \\
\hline & & Total & 120 & & 71 \\
\hline
\end{tabular}


When we look for the distribution of opinions of students related to the demand for the existence of a centre where there are teacher in all branches, 41 of secondary school students said "I want", 12 of which said "No, I don't want" and 7 of which stated their doubts by saying "I don't know whether it is useful or not". In this question, it is also seen that high school students are at the forefront with regard to their sensitivity to the model.

Students demanding the Teaching-Family Centres expressed their opinions considering three important sub-themes. The first one of sub-themes is the fact that the classes are too crowded. Students stated that they couldn't understand and follow the lesson by expressing that the classes were too crowded. The second of these sub-themes is the fact teachers do not give individual attention to students. In this sub-theme, students stated that they demanded the existence of centres where there are teachers to give individual attention by saying that teachers did not give individual attention to them. The third sub-theme is the fact that students do not have suitable family environment for studying. The students stated that they demanded these centres by showing the reason that their family environment was not suitable for studying, they didn't have own rooms and nobody could help them for their lessons. The main reason of students for demanding this model is meaningful with regard to the fact that it is also the main reason for the model. Some examples of the opinions of students related to this model are given below.

A student complaining about crowded classes mentioned the reason of demanding these centres as follows: We have too crowded class. Everyone talks at all once. We generally cannot hear what the teacher says. We need a teacher giving individual to us especially in quantitative courses (B1S11-98). Another student said "If there was such a centre, I would correct my deficiencies by asking my questions that I answered wrongly in tests (B1S11-78)". A secondary school student expressed the demand of these centres by saying "The class is too crowded, we cannot ask what we don't understand. As the teacher cannot shut the class up, he is always nervous and shouts. There are so many naughty students in our class (A2S655)". A high school girl student tells her complaint about crowded house as: I have 9 siblings. We are almost the same age. Girls are more than boys. Our father is the elder of our relatives. Everyone comes visit him. Therefore, our house is so crowded that I cannot find a place to sit rather than to study. If there was such a centre, I would go there to study. If there is an opportunity, I believe that I can be successful (B3S10-117). The opinion of another student is as follows: I came here this year. Our class is too crowded. The teacher cannot give attention to all of us. If there was a place like this, I would ask the teachers in these centres my questions that I cannot ask to the teachers in my school (A3S7-48). The opinions of students related to whether this centre is paid or free are stated in Table 5.

Table 5. Opinions of Students related to whether "Teaching-Family Model" is paid or free

\begin{tabular}{|c|c|c|c|c|c|}
\hline Main Theme & $\begin{array}{l}\text { Education } \\
\text { Level }\end{array}$ & Answers & $\mathbf{f}$ & Sub-Themes & f \\
\hline $\begin{array}{l}\text { the fact that students } \\
\text { demand such a centre } \\
\text { whether paid (private) } \\
\text { or free (state) }\end{array}$ & $\begin{array}{l}\text { Secondary } \\
\text { school }\end{array}$ & $\begin{array}{l}\text { Should free paid } \\
\text { Neutral } \\
\text { Should be paid } \\
\text { Should be free } \\
\text { Neutral } \\
\text { Should be paid }\end{array}$ & $\begin{array}{l}53 \\
-- \\
7 \\
54 \\
-- \\
6\end{array}$ & $\begin{array}{l}\text { Insufficient economic conditions of } \\
\text { families } \\
\text { The fact that students feel themselves under } \\
\text { psychological pressure as their families } \\
\text { provide them with additional paid (private) } \\
\text { education opportunity }\end{array}$ & 68 \\
\hline & & Total & 120 & & 110 \\
\hline
\end{tabular}

When we look for the distribution of the opinions of students whether the centre where there are teachers in all branches should be paid (private) or free (state), while 53 of 60 secondary school students participating the research states that these centres should be free, 6 of which states that they should be paid (private). The fact that these centres should be opened by the State as free was stated by almost all secondary and high school students. This decision 
of students is important for recalling that the education service is under the responsibility and liability of the state.

The opinions of students related to this main theme of the research focus on two subthemes. One of these sub-themes is the theme the most emphasized by students and especially related to the economic conditions of family. In this respect, students mentioned the inadequate economic conditions of their families and concordantly their complaints arising from unfair competition. In this sub-theme, students tried to emphasize that preparing the same examination with different opportunities was unfair. The second sub-theme is the fact that students whose families provide additional paid (private) education opportunity feel themselves under psychological pressure. As these families providing private educational support for their children mention frequently this situation especially during exam periods, they cause adverse psychological effect on their children. Students stated that this pressure affect their success adversely and expressed that there should be such centres.

A high school student demanding free teaching-family centres made the following explanation: I will enter into university examination next year. Private teaching institutions are getting closed. The ones who have money take private courses. The economic condition of my family is not adequate for providing me these private courses. If there is such a model, I will always study in these centres. Thus, I don't impose on my family. Probably, the State wants everybody to go to private schools (B3S11-112). Another student wants TeachingFamily Centres to be opened by stating "if there is such a centre, those who have no money can get into good colleges and at least the equality can be provided (B1S10-72)". Another student expresses her feeling as "My father every time mentions how much money he paid for private teaching institutions. He says that if I cannot succeed, money will go for nothing. This makes me stressful. If there is such a centre as free, I will be more relaxed without being under pressure (B1S10-72)". "Let them build these centres in Eyübiye. The families of children in here are poor. If they benefit from these centres, they can save themselves (A1S634)". Another student complaining that his family have him worked expresses his feelings: If the State doesn't receive money from us, give money to our family for schooling us, our family doesn't have us worked (B1S10-72). A student who states that these centres should be paid says, "I think that these centres should be paid and have owners and everything should be serious. If they are free, everyone comes. So they will be crowded. The teachers will have difficulty in giving special attention. So we cannot study adequately (A2S6-13)". The opinions of students related to the effect of these centres on their success are given in Table 6 .

Table 6. Opinions of Students Related to the Effect of "Teaching-Family Model" on their Success

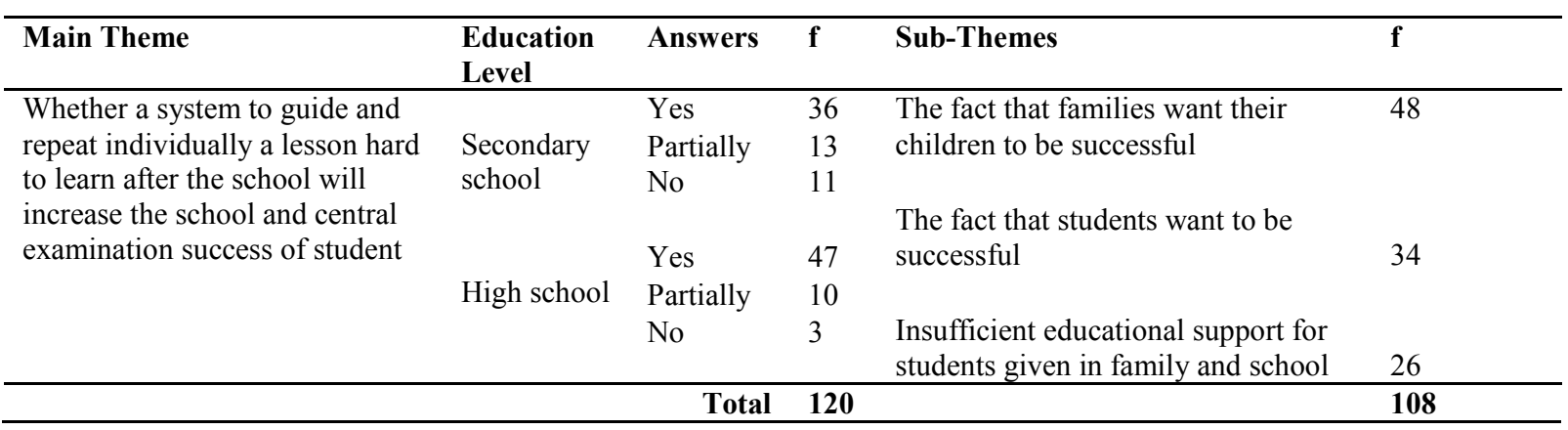

The opinions of students related to whether a system to guide and repeat individually a lesson hard to learn after the school will increase their success in school and central examination show distribution as follows: 60 secondary students participated the research and answered the question; 36 of which answered as "yes", 13 of which as "partially" and 11 of 
which as "no". While 47 of 60 high school student participating the research believe that this model will increase their success, 10 of which believe partially, 3 of which state that the model will not have an effect on their success. Although the students generally express positive opinion on the effect of "Teaching-Family Model" on student success, it is seen that high school students are more optimist in this matter.

The opinions of students relating to the effect of "Teaching-Family Model" on their success can be grouped into three sub-themes. The first one of these sub-themes is the fact that families want their children to be successful and this matter is known by students. The second sub-theme is the fact that students want to be successful. The students discussing this theme states that they want to study but they cannot study due to insufficient opportunities and so they think that these centres will increase their success. In the third sub-theme, the students discuss the lack of educational support. In this sub-theme, the students complained the economic insufficiency of their families, the obligation of household chores and looking after a baby and stated that they could not adequately make use of the school. These students think that they can be successful by making use of their leisure time well in these centres. Some examples of the opinions of students relating to this main theme are given below.

A high school student expresses his opinion related to the fact that the model will affect positively his success: The teacher give a lecture on math and solve problems on blackboard. I sit at the back of classroom. I sometimes miss what the teacher says. I also cannot understand completely. I think that I will understand better if a teacher gives me lecture again. I pay attention to the courses, my teacher knows this (B3S11-81). Another student states, "I know that we have little time, for this reason I want to study hard. I want to review the lessons. So I want a teacher to give me lecture again B1S11-73)". A secondary school student states that Teaching-Family centres will increase the success by saying " $M y$ family already tries to decide on which high school I should go. They are happy when I take high grades. If there are such centres, my grades will be better (A1S7-11)". A student in $10^{\text {th }}$ grade of high school expresses her fear to drop out and her longing to success by stating " $I$ cannot go to school regularly due to some of my problems. I should look after my siblings. I sometimes make household chores. If my father let me go to school, I will go to those centres and will study hard and become very successful (B2S10-95)". My family want to be very successful. I want also, but our school is too crowded. Our teachers constantly changes. I cannot understand the lessons, so I'm upset. If there is such a place that you've told, I will go there and become very successful (A3S7-57). A student tells the benefits of taking lessons in many places: I have friends who both go to private teaching institution and take private courses. They are very successful, because they listen to the teacher in the school and repeat these lessons in the private teaching institution and by private courses. I also go to the private teaching institution, but it is also too crowded. The Teaching-Family centres will increase our success (B2S11-68). A student who thinks that the Teaching-Family centres will not affect the success of student expresses his opinion, "The one who want to study can study everywhere". The opinions relating to the fact that students are bothered by teachers constantly giving attention to them, correcting their deficiencies after the school, following them in the school and informing their family or school about them are given in Table 7. 
Table 7. The Opinions of Students related to the fact that the function of "Teaching-Family Model" will bother them

\begin{tabular}{|c|c|c|c|c|c|}
\hline Main Theme & $\begin{array}{l}\text { Education } \\
\text { Level }\end{array}$ & Answers & $\mathbf{f}$ & Sub-Themes & $\mathbf{f}$ \\
\hline \multirow{3}{*}{$\begin{array}{l}\text { The fact that students are } \\
\text { bothered by teachers constantly } \\
\text { giving attention to them, } \\
\text { correcting their deficiencies } \\
\text { after the school, following them } \\
\text { in the school and informing their } \\
\text { family or school about them }\end{array}$} & $\begin{array}{l}\text { Secondary } \\
\text { school }\end{array}$ & $\begin{array}{l}\text { Yes } \\
\text { Partially } \\
\text { No }\end{array}$ & $\begin{array}{l}12 \\
14 \\
34\end{array}$ & $\begin{array}{l}\text { Opinions of students related to the fact } \\
\text { that their family will be satisfied }\end{array}$ & 28 \\
\hline & High school & $\begin{array}{l}\text { Yes } \\
\text { Partially } \\
\text { No }\end{array}$ & $\begin{array}{l}9 \\
18 \\
33\end{array}$ & $\begin{array}{l}\text { Requirements of students for learning } \\
\text { their deficiencies and receiving guidance }\end{array}$ & 23 \\
\hline & & Total & 120 & & 51 \\
\hline
\end{tabular}

When we look for the distribution of the opinion of students related to the fact that they are bothered by teachers constantly giving attention to them, correcting their deficiencies after the school, following them in the school and informing their family or school about them, while only 12 of 60 secondary school student participating the research state that they will be bothered, 14 of which state that they will be partially bothered and 34 of which state that they will not be bothered. While 9 of high school students state that they will be bothered, 18 of which state that they will be partially bothered and 33 of which state that they will not be bothered. When we look in general, it is seen that the opinions of secondary and high school students show balanced distribution and the students state that they will not be bothered by teachers constantly giving attention to them, correcting their deficiencies after the school, following them in the school and informing their family or school about them.

The opinions of students relating to this matter consist of two sub-themes. The first one of these sub-themes is the opinions of students related to the fact that their family will be satisfied. The students are of the opinion that families can make easily both physical followup and the success follow-up of their children through this system. The second sub-theme is the approaches of students relating to knowing their deficiencies and receiving guidance. In this sub-theme, the students state that the system will not bother them by aping their friends who take private courses. Moreover, the students state that they will adopt and support more this system within the scope of this main theme and its sub-themes. Some examples of the opinions of students relating to the fact that they are bothered by teachers constantly following their success, informing their family or school about them are given below.

A student who assessed the existence of Teaching-Family centres with regard to his family expressed his opinion, "My family will be the most pleased for this situation. Every time, they ask me where I am (A3S7-43)". Another student responding positively that the teachers in Teaching-Family centres take on such a task expresses his opinion, "I want to go to the medical faculty, for this reason I study hard. My family and also my teachers trust me, but I don't know what my deficiencies are. I don't know for which subject I should pay more attention or how much and which kind of questions there are in the examinations. The teachers in these centres may tell me my deficiencies by reviewing my preparatory exams. They may also guide me for studying regularly (B3S11-87)". Another student states, "Who wouldn't want a free tutor (B3S11-113". I have friends who take private courses. They know what their deficiencies are. Their tutors have prepared a program for them. They follow them through this program and their success in exams. The centres which you've told would be great for us (B2S11-67). 


\section{RESULT AND DISCUSSION}

In this section of research, the following results were reached by grouping data collecting depending upon the opinions of participant students related to the "TeachingFamily Model" firstly as main themes and then sub-themes.

In the research, before taking the opinions of students on the model, it was asked to the students whether they understood it completely or not. It was revealed that almost all of the students understood rightly the model. This shows that the model is simple and apprehensible. The second question asked to the students relating to the structure of model is associated with the applicability of model. It was understood that most of the students had the opinion that the model was applicable. With reference to this finding, it can be said that the model have simple and applicable characteristic. The students greatly lean to the fact that the model is completely apprehensible and applicable for students, which reveals the requirement of such a model. It was revealed that the high school students paid more attention to the model and had more positive opinion than the secondary school students in both questions. Şimşek \& Şimşek (2014) states that seeking the resource to help children in their school lessons is day-by-day increasing in their study themed reconsidering the studies centres within the context of family transformation and family responsibility.

The opinions of students who demand the centres where there are teachers in all branches giving individual attention to them were grouped into three sub-themes. The first sub-theme includes the complaints of students for too crowded classes in schools. The students stating that the courses pass inefficiently due to naughty students and too crowded classes emphasize that the schools cannot prepare students for examinations with their current condition. The second sub-theme including the opinions of students is the matter that teachers do not give individual attention to students and teach them without considering their individual characteristics so the lessons cannot be adequately understood. In this theme, the students state that the teachers do not give individual attention to them, which shows the need of the existence of Teaching-Family centres where there are teachers to give individual attention to them. And the third sub-theme including the opinions of students is the fact that the family structure and houses of the students are not suitable for studying. In this theme, the students emphasize that their house is not suitable environment for studying and there is no one to help them for their courses at their house, for this reason they demand the TeachingFamily centres. In this regard, the families may make sacrifice and create suitable environment, but it is almost impossible that individuals can help their children in all branches. This shows that the students are right for their complaints. Considering the opinions in sub-themes included within the context of this main theme, it can be said that the school and family environments are inadequate for the preparation of students for central examinations. The opinions of students relating to the inadequacy of their school and family environment are the reasons for their demand for this model. The main reasons for the demand of students for this model are meaningful as they are the basic principles of model at the same time. In consideration of these evaluations, in literature, the fact that a student corrects his/her deficiencies by mutual interaction with a teacher, recognises his/her learning performance and controls his/her learning by receiving feedback facilitates to attain his/her goals (Baki \& Güven, 2008). Likewise, the individual teaching provides students with important gains in discovering the graded questions and mathematical relations of solution supports, finding formulas and permanent learning (Özyurt at al, 2014). Zeki and Güneyli (2014) state that student-centred learning approaches contribute to the development of social, emotional and mental skills of students. 
The opinions of students demanding free Teaching-Family centres which are related to this main theme were classified as two sub-themes. The sub-theme that the students put emphasis on most is the theme expressing the economic conditions of families. When considering that this study was made in a region where there are so many seasonal worker families and juvenile labours, it can be said that this result becomes meaningful. Besides, the students emphasize in this theme that preparing the same examination with different opportunities is not fair. As for the other sub-theme, the students whose families provide additional private education opportunity for them feel themselves under psychological pressure. The fact that the students who take private courses or go to expensive private teaching institutions emphasize that they feel themselves under pressure can be accepted as a sign of the need for Teaching-Family Centres. Another reason that the students feel themselves under psychological pressure is the fact that their families frequently mention the expenses of their education especially in the examination period. If the Teaching-Family centres are free, this will provide the students with additional education opportunity and result in increasing success as they are no more under psychological pressure. Thus, this points out that the schools need an education suitable for today's conditions out of their senses of classical education. Akpinar \& Gezer (2010) conclude through their study that our secondary education schools are greatly under the influence of traditional education approaches in spite of all their change and renewal discourses.

The opinions of students relating to the effect of Teaching-Family centres on their success which is another main theme are grouped into three sub-themes. The first sub-theme is the fact that families want their children to be successful and this situation is known by the students. Most of the students stated that they want to be successful for satisfying their families, for this reason they need these centres. The second sub-theme discussed in this main theme is the fact that the students want to be successful without taking economic support from their families. For this reason, it can be said that as the students who want to study and become successful do not have adequate educational support, they demand the TeachingFamily centres to be opened. Thus, these centres provide students with the competition opportunity and may also provide opportunities for their success. The inadequacy of education support for students forms the third sub-theme. The fact that students have to work due to the poor economic conditions of their families causes them to fall behind in the class. Especially children of seasonal worker families come to school two months after the starting of semester and leave the school two months before the end of semester. Some families do not send their children to school -especially their daughters for having them do the household chores-. Due to the abovementioned reasons, the children cannot benefit from the schools during the semesters. These students can become successful by making use of these centres during their leisure times. Özyurt at al. (2014) state that the individual learning contributes to the students for facilitating to learn, providing permanent learning and learning by discovery. Reynolds (1991) emphasizes the importance of individual attention in this study by stating that secondary school years are a critical period for mathematical and science success of the students. Sümbül \& Yurt (2014) indicate that cognitive and motivational variables affecting the mathematical success of students should be handles as a whole and the suitable environments should be created.

The opinions of students relating to the fact that students are bothered by teachers constantly giving attention to them, correcting their deficiencies after the school, following them in the school and informing their family or school about them consist of two subthemes. The first sub-theme is the satisfaction of student families for this application. The students are of the opinion that their families and schools will be informed better about their success through this application. With this finding, it can be concluded that the deficiencies 
and mistakes of the students can be determined and corrected easily. The second sub-theme is associated with the demand of students for getting guidance service for correcting their deficiencies. In this theme, the students state that the existence of a centre and teachers to give individual attention to them will not bother them and they will be satisfied by this application. In case of its application, it is seen that such centre and studies will be adopted by the students. This will allow students to increase their academic success. Bilgi at al. (2014) prove that the students can be successful if they endeavour and have a successful school experience in the past and so they have successful academic experiences. Akın \& Aslan (2014) determine that the success is associated with the determination and the determined students have high success chances. Joyce, Weil \& Calhoun (2009) emphasize in their study named Teaching Models that the use of various teaching models affects positively the success of student.

It is known that Turkish education system is exam-centred and students in almost all education levels take central examinations and prepare for these examinations. In fact, secondary and high school students are not satisfied with the resources that schools provide and seek for alternative resources. By depending upon the opinions of students, we can easily say that the Teaching-Family Model setting forth health solution of this alternative resource seeking and subject of our study can be adopted by the students and will increase the success of students. The students approve that this model deemed as adopted by families and students, reducing the load of school and enabling the increase of their success by providing them safe studying environments is applicable.

\section{REFERENCES}

Akın, A. \& Aslan, S. (2014). The Effect of Peace Education Program on The Seven -Grade Student's Conflict Resolution and Communication Skills. Education and Science, 39 (175), 309-318.

Akpınar, B. \& Gezer, B. (2010). Learner-Centered New Educational Paradigms and Their Reflections on the Period of Learning and Teaching. Dicle Üniversity Journal of Ziya Gökalp Education Faculty, 14, 1-12.

Ames, C. (1992). Classrooms: Goals, Structures, and Student Motivation. Journal of Educational Psychology, 84(3), 261-271.

Baki, A. \& Güveli, E. (2008). Evaluation of a Web Based Mathematics Teaching Material on the Subject of Functions. Computers \& Education, 51(2), 854-863.

Bernfeld, GA. Blase, KA. Fixsen DL. (1990). Towards a Unified Perspective on Human Service Delivery Systems: Application of The Teaching-Family Model, Behavior Disorders of Adolescence. Edit by R, J. Mcmahom and R. DeV Peters, Press New York.

Bilge, F. Dost, M. T \& Çetin, B. (2014). Factors Affecting Burnout and School Engagement among High School Students: Study Habits, Self Efficacy Beliefs, and Academic Success. Educational Sciences: Theory \& Practice, 14(5), 1709-1727

Brown, E., (2007). The Use of Learning Styles in Adaptive Hypermedia, Unpublished PhD Thesis, The University of Nottingham, England.

Brown, E., Brailsford, T., Fisher, T., \& Moore, A. (2009). Evaluating Learning Style Personalization in Adaptive Systems: Quantitative Methods and Approaches. IEEE Transactions on Learning Technologies, 2(1), 10-22.

Brusilovsky, P. \& Peylo, C. (2003). Adaptive And Intelligent Web Based Educational Systems. International Journal of Artificial Intelligence in Education, 13, 156-169. 
Cabada, R.Z., Estrada, M.L.B., \& Garcia, C.A.R. (2011). Educa: a Web 2.0 Authoring Tool for Developing Adaptive and Intelligent Tutoring Systems Using a Kohonen Network. Expert Systems with Applications, 38(8), 9522-9529.

Dean L. F., Karen A. B., Gary D. T. \& Montrose M. W. (2007). In Search of Program Implementation: 792 Replications of the Teaching-Family Model. The Behavior Analyst Today, 8 (1), 96-110.

Dean L., Karen A., Gery D. \& Monterise M. (2001). In Search of Program Implementation: Replications of The Teaching Family Model. john Wilay and Sons Ltd. Kansas USA.

Doğanay A. (2007). Teaching Principles and Methods, Ankara: Pegem Akademi Publishing,

Ekici, G. (2003). Based on Learning Styles Teaching Towards Education and Biology Course Syllabus Examples. (1. Print) Ankara: Gazi Publishing House..

Fielding, N. (1996). Qualitative Interviewing.K.Punch (Ed.), Introduction to Social Research, London: Sage.

Joyce, BR, Weil, M ve Calhoun, E. (2004). Models of Teaching. Allyn and Bacon California Üniversitesi, Dijital ortama aktarılış tarihi, 1 Aralık 2009.

Kirigin, KA Braukmann, CJ Atwater, JD (1982). An evaluation of teaching $\square$ family (Achievement Place) group homes for juvenile offenders. Journal of Applied, Wiley Online Library.

Lddle, H. A. . \& Saba, G.V. (1982). Teaching Family at The Introductory Level: Conceptual Model Emphasizing Pathern Vhich Connects Traning and Therapy. Journal of Marital and Family Therapy, 8(1), 63-72.

Hund, R. (2013). The Social Family Model of Teaching. Retrieved December 12015 , https://prezi.com/-w3tiiwwiitg/the-social-family-model-of-teaching/.

Kuzgun, Y. \& Deniz D. (2004). Ĕ̈itimde Bireysel Farklılıklar. (2.Bask1). Ankara: Nobel Yayın dağıtım.

Jimerson SR, Oakland TD \& Farrell PT. (2007). The Handbook of International School Psychology. Thousand Oaks, CA: SAGE.

Minichiello, V., Aroni, R., Timewell, E. \& Alexander, L. (1990). In-depthinterviewing: Researching People. Melbourne: Longman Cheshire.

Molla, N. \& Lazarrus, S. (2014). School Psychologists' Views on Challenges In Facilitating School Development Through Intersectoral Collaboration. South African Journal of Education, 34(4)909-919.

Mustafa, Y.E.A. \& Sharif, S.M. (2011). An Approach to Adaptive e-Learning Hypermedia System Based on Learning Styles (AEHS-LS): Implementation and Evaluation. International Journal of Library and Information Science, 3(1), 15-28.

Reece,J \& Walker, S. (1997). Teaching Training and Learning "a Practical guide”. Business Education Publishers.

Tan, Ş. (2006). Öğretimi Planlama ve Değerlendirme. (10. Bask1), Ankara: PegemA Publishing.

Özgüven, İ. E. (2005). Bireyi Tanıma Teknikleri. Ankara: Nobel Yayın Dağıtım. 
Tseng, J.C.R., Chu, H.C., Hwang, G.J., \& Tsai, C.C. (2008). Development of an Adaptive Learning System With Two Sources of Personalization Information. Computers \& Education, 51(2), 776-786.

Şimşek, H. \& Şimşek, S. (2014).Thinking Again The Study Center In Terms of The Responsibilty of Family and Its Transformation,_Kastamonu Education Journal 23 (1), 365-384.

Şimşek, H. (2010). Educational Problems in Ottoman Empire: A Historical Case Study About Road Security (Traffic) and School Services Kuramsal Eğitimbilim, 3 (1), 135-147.

Wolf, MM., Phillips, EL., Fixsen, DL. \& Braukman, CJ. (1976). Achievement Place: The Teaching- Family Model. Child Care Quarterly, 5, (2), 92-103.

Wrestling, D. (1995). The Teaching-Family Model A Case Study in Data-Based Program Development and Refinement. Journal of Organizational Behavior Management. $15, \underline{1-}$ $\underline{12}$.

Yıldırım, A. \& Şimşek, H. (2008). Qualitative Research Methods in Social Sciences. (5. Print). Ankara: Seçkin Publishing House.

Y1ldırım, S. (2007). Current Utilization of ICT in Turkish Basic Education Schools: a Review of Teacher's Ictuse and Barriers to İntegration. International Journal of Instructional Media, 34 (2), 171-186.

Yin, R. K. (2003). Case Study Research.Design and Methods. Thousand Oaks, CA.: Sage.

Yurt, E. \& Sümbül, A. M. (2014). A Structural Equation Model Explaining 8th Grade Students' Mathematics Achievements. Educational Sciences: Theory \& Practice, 14(4), $1629-1653$

Zeki, C.P. \& Güneyli, A. (2014). Student Teachers' Perceptions about Their Experiences in a Student Centered Course, South African Journal of Education, 34, (3), 929-940. 